\title{
Training Strategy Research of Mechanical and Electrical Specialty Teachers Under the Background of New Engineering
}

\author{
Ji Yongzhi*1 \\ ${ }^{I}$ School of mechanical and electrical engineering, Binzhou University, Binzhou, 256603, China \\ *Corresponding author Email: myjoblist@163.com
}

\begin{abstract}
As the guiding ideology of the current higher engineering education reform, new engineering not only puts forward new requirements for the professional training of outstanding talents in colleges and universities, but also points out a new direction for the engineering construction of teaching staff. Taking the construction of teacher training system of mechanical and electrical specialty as the research object, based on the interpretation of the connotation and significance of new engineering, this paper analyzes the basis of teacher training of mechanical and electrical specialty under new engineering, and analyzes the construction of teacher training system of mechanical and electrical specialty under the background of new engineering construction from four aspects. The research results provide a strong reference for Local Application-oriented colleges to carry out the construction of new engineering teachers.
\end{abstract}

Keywords: New engineering; training system; horizontal projects; aviation characteristics

\section{INTRODUCTION}

After more than 40 years of reform and opening up, China has made remarkable achievements. Now China is the world's second largest economy and the world's largest industrial country. Engineering education, as an important support for China's industrial development, is continuously providing talents for China's industrial development. In the 1950s, China's higher education made clear the development idea of engineering priority. With the deepening of industrial construction, China's engineering education has experienced technological paradigm, scientific paradigm, and today's engineering paradigm [1]. At present, our country has entered a new era of national development. General Secretary Xi Jinping has made important discussions on the new round of technological revolution and industrial transformation on many occasions. This not only points out the direction for engineering education, but also puts forward new requirements for engineering education. The concept of new engineering is put forward under the above background[2-3].

With the development of "Fudan consensus", "Tianda action" and "Beijing Guide", new engineering construction and engineering education reform set off a new upsurge in China [4].This paper takes Binzhou
University of Shandong Province as an example, based on the mechanical and electrical specialty of aviation characteristic application-oriented universities, takes the training of new engineering talent standard and mechanical and electrical industry talent standard as the basis of teaching staff construction, and analyzes the new engineering teaching staff construction plan from the aspects of occupation hobby, skill training, professional migration and multiple evaluation. This provide important reference to broaden the development path of "double-qualified teacher $\rightarrow$ key teacher $\rightarrow$ team leader $\rightarrow$ master teacher", and build a "pyramid" of new engineering teacher echelon, and improve the selection mechanism of new engineering master teachers and discipline leaders.

\section{INTERPRETATION OF THE CONNOTATION OF NEW ENGINEERING}

The concept of new engineering was first proposed in 2016, which sounded the clarion call for the reform of engineering education in China. In February 2017, the Ministry of Education held a seminar on the development strategy of Higher engineering education in Fudan University, and issued the notice on carrying out new engineering research and practice, which pointed out "the 
vigorous development of new economy represented by new technology, new format, new mode and new industry, has put forward higher requirements for engineering and scientific talents", and from the "new concept, new structure, new mode, new quality, new system" five levels summed up the content of new engineering [5].At present, there are many policies and researches on the construction of new engineering. Summarizing the previous views, we can find that the connotation of new engineering mainly includes the following three aspects:

First, put forward new ideas. The proposal of new engineering has a profound realistic background and is the product of Higher engineering education Responding to the changes of the new economic era. Therefore, integrating into the development of the intelligent era and coping with the industrial challenges has become the basic concept of new engineering talents training. At the same time, with the innovation of education concept and education mode, new engineering shoulders the historical mission of actively shaping the world, which is a major breakthrough in driving the development of the times [6].

Second, issue new requirements. From the perspective of talent training quality, new engineering construction not only focuses on the cultivation of professional ability and practical skills, but also on the cultivation of innovation consciousness, leadership ability and lifelong learning quality. From the perspective of personnel training structure, the new engineering greatly enriches the personnel training structure of engineering. While meeting the development needs of the times, it also puts forward new requirements for the direction of engineering specialty and the subdivision of talent level.

Third, point out the new way. On the one hand, the new engineering inherits the successful experience of previous engineering education and continues the traditional craftsmanship spirit of the Chinese nation; On the other hand, the new engineering has a strong innovation, both in the personnel training resources, or in the personnel training mode, there are great changes, and emphasis on the cross integration of engineering majors and the coordination and sharing of engineering education [7].

With the strong support of the state, the construction of new engineering has increasingly become the key content to reshape the engineering of China's higher education and optimize the quality of engineering personnel training [8]. China's higher education is facing the challenge of new engineering talents training needs. Practice "new engineering" training mode of innovative talents training to output high-quality applied talents serving production enterprises, so as to promote the reform of new engineering technology and the upgrading of new industries [9].Therefore, "new engineering", as the key to the transformation of engineering education paradigm in the new economic era, has opened a new exploration of engineering education in applicationoriented higher education. The construction of teaching staff is the endogenous power of new engineering construction, and the main driving force to enhance the core competitiveness of aviation characteristic application-oriented universities.

\section{THE BASIS OF TEACHERS' ABILITY TRAINING OF MECHANICAL AND ELECTRICAL SPECIALTY UNDER THE BACKGROUND OF NEW ENGINEERING}

As an application-oriented undergraduate university with aviation characteristics, the basis for training mechanical and electrical specialty teachers comes from two aspects: the quality assurance system of talents in new disciplines and the development needs of mechanical and electrical industry in regional new economy. Therefore, in order to train the teaching staff of electromechanical specialties in aeronautical characteristic colleges and universities, we should establish the training objectives and requirements for graduation, talent training standards, excellent engineering training plans and specific teaching resources based on the above two aspects, and adopt multiple evaluation standards to complete the orientation of the training of teachers.

\subsection{Teacher Training Based on New Engineer- ing Talent Training Objectives}

The main body of mechanical and electrical teachers should have a forward-looking vision of new engineering talents training. The main body of education should know that new engineering is the guide of education reform for the construction of quality system of engineering talents in higher education, set the training objectives and graduation requirements of electromechanical talents in order to serve the local new economic development, and fully study the positioning of Electromechanical industry and aviation related industries for talents on the basis of reflecting the aviation characteristics of local universities. The core of teacher training is to improve their practical ability.In the goal of new engineering talents training, we should design teaching resources well, in terms of personnel training plan, curriculum syllabus and teaching mode, focus on engineering application of mechanical and electrical technology under new engineering.

\subsection{Teacher Training Based on the Develop- ment of New Engineering Electromechanical Industry}

As a teacher of mechanical and electrical specialty, he should pay attention to the innovation of production practice and innovate the concept, task and mode of talent 
training from all aspects of talent training, which is a new paradigm to promote the systematic and holistic reform of Higher engineering education [10]. In the environment of new engineering construction, the teaching and scientific research activities of teachers' groups should firmly grasp the aviation characteristics, actively integrate into the innovative training platform jointly built by university, enterprises and local governments, build a first-class discipline on the basis of new engineering specialty construction, promote online and offline mixed teaching, and improve the effect of talent training. In addition, under the new economic format, the electromechanical industry should have the open spirit of professional integration, and take the cross integration of multiple majors in college and universities as an important part of the new talent training mode [11]

\section{DECONSTRUCTION OF TEACHER TRAINING SYSTEM OF MECHANICAL AND ELECTRICAL SPECIALTY OF NEW ENGINEERING}

Combined with the basis of teacher training proposed above, we can analyze the teacher training system of mechanical and electrical specialty from four levels: practice analysis, problem solving, cross integration and multiple evaluation. As shown in Figure 1, each level requires local application-oriented universities to carry out corresponding training plans in combination with their own school running characteristics.

\begin{tabular}{|c|c|c|}
\hline Exploration & $\begin{array}{l}\text { Practice } \\
\text { analysis }\end{array}$ & $\begin{array}{l}\text { 1. Combining theory with practical engineering application; } \\
\text { 2. Engineering teaching research. }\end{array}$ \\
\hline Development & $\begin{array}{l}\text { problem } \\
\text { solving }\end{array}$ & $\begin{array}{l}1 \quad \text { Engineering } \quad \text { application } \\
2 \text { Engineering application of electromechanical technology. }\end{array}$ \\
\hline Migration & $\begin{array}{l}\text { Cross- } \\
\text { integration }\end{array}$ & $\begin{array}{l}1 \text { Multidisciplinary Developmen; } \\
3 \text { Engineering Professional Quality. }\end{array}$ \\
\hline Evaluation & $\begin{array}{c}\text { Multi- } \\
\text { assessment }\end{array}$ & $\begin{array}{l}1 \text { Professional Assessment; } \\
3 \text { On-campus Identification. }\end{array}$ \\
\hline
\end{tabular}

Figure 1 Deconstruction of teacher team training system

\subsection{New Engineering Ideology Oriented by Engineering Practice Ability}

As teachers of mechanical and electrical specialty, they can improve their engineering literacy from three aspects: (1) education and teaching. The development of mechanical and electrical specialty in applicationoriented universities is closely combined with the demand of engineering talents in the local new economic industry to cultivate students' production practice ability in the mechanical and electrical industry, carry out indepth cooperation with local enterprises, and establish school enterprise practice base. (2) horizontal research projects. collegess and enterprises carry out various forms of cooperative research and transformation of scientific and technological achievements in production. Through the joint laboratory built by colleges and enterprises, the combination of human innovation and enterprise production can be realized, the practicability of research achievements can be improved, and the basic research achievements can be transformed into applied research. (3) industry digitization. Mechanical and electrical professional teachers team should strengthen the service of local industry digitization, provide professional technical guidance, consultation, technician training, product testing and analysis, and act as enterprise technical consultant for enterprises.

\subsection{The Application of Mechanical and Electri- cal Technology Innovation to Achieve Training Orientation Transfer}

Under the background of new engineering, the cultivation of mechanical and electrical professional teachers must focus on innovative training methods to realize the cross integration of teachers' ability with other related professional fields. First of all, one-to-one support for new and old teachers can be carried out under the background of new engineering, because the interdisciplinary senior teachers and young mechanical and electrical teachers have their own advantages in teaching and scientific research, just forming a complementary role; second, we should pay attention to the innovative application of scientific research team, and improve the overall scientific research ability and teaching ability of teachers with the help of subject research and teaching and research plan preparation, so as to realize the goal of scientific research Finally, we should further carry out school enterprise cooperation and industry university cooperation to increase the practice opportunities of teachers, so as to continuously improve the engineering professionalism of teachers.

\subsection{Establish a Scientific and Long-term Multi- ple Evaluation Mechanism}

The local government should strengthen the policy support for the construction of new engineering courses 
in college and universities, and provide relevant support for the training of mechanical and electrical teachers in colleges and universities. The management of colleges and universities should have the strategic vision of training new engineering teachers, so that the training of teachers' engineering practice ability is not only limited to immediate skill training, but also to form a long-term mechanism of knowledge structure optimization and engineering ability training.

\section{CONCLUSION}

From the perspective of the construction of mechanical and electrical specialty in Local Applicationoriented collegess, the team of engineering teachers under the new engineering course can better understand the industrial development trend of mechanical and electrical industry and the demand of enterprise manufacturing, which will inevitably lead to more horizontal projects and related funds in universities, and higher conversion rate of industrial achievements. In addition, no matter the development of the major itself or the cross integration with other majors, the development of mechanical and electrical majors should be closely related to the connotation and requirements of the new economic formats, and continuously optimize the training of teachers. Therefore, this paper puts forward the new engineering electromechanical teacher training model, including four aspects: training subject, innovative training methods, improving training resources, and improving the guarantee mechanism, which provides decision support for Local Applicationoriented collegess to further improve the engineering practice literacy and innovation ability of professional teachers. For the further development of new engineering in Local Application-oriented colleges and universities, the decision-making level of colleges and universities should deepen and enhance the theoretical framework of the construction of mechanical and electrical engineering teachers' team oriented by practical ability, and gradually build and improve the system framework of teachers' professional training and evaluation.

\section{ACKNOWLEDGMENTS}

The work was supported by the Binzhou University Doctoral Start-up Project(2017Y21).China's Education Ministry's Industry-university Cooperative Educational Project: Construction of Intelligent Manufacturing Virtual simulation Laboratory(2021).

\section{REFERENCES}

[1] Ma Dehui, Liu Jie, Jiang Ning. The Overall Paradigm Outlook of Public Security Intelligence Studies in a New Security Era [J]. Journal of Intelligence, 2018,37(10):12-18.
[2] Zhong Denghua. Connotations and Actions for Establishing the Emerging Engineering Education[J]. Research in Higher Education of Engineering,2017( 3):1-6.

[3] Gu Peihua. The Concept, Framework and Implement Approaches of Emerging Engineering Education (3E) and the New Paradigm[J]. Research in Higher Education of Engineering,2017( 6):1 - 13.

[4] Wu Aihua, Hou Yongfeng, Yang Qiubo, et al. Accelerating the development and construction of new engineering, actively adapting to and leading the new economy. Research on higher engineering education, 2017 (1): 1-9.

[5] Wu Tao,Wu Fupei,Bao Nengsheng,Niu Xiaodong.A Study on the Essence of the Connotation Development of Emerging Engineering[J].Research in Higher Education of Engineering, 2018( 6):1622.

[6] Lin Jian.The Construction of China'a New Engineer Disciplines for the Future[J].Tsinghua Journal of Education,2017( 2):26-35.

[7] Xia Jianguo, Zhao Jun. On the Reform and Development of Engineering Education in Local Universities and college Based on Establishing Emerging Engineering Education[J]. Research in Higher Education of Engineering,2017( 3):21 - 25.

[8] Jiang Xiaokun, Zhu Hong, Li Zhiyi.A New Mode of Talents Training under the Background of New Engineering Education[J]. 2018( 2):23-30.

[9] Tang Hehua.Research on the reform of local universities and colleges' applied talents cultivation[D].Suzhou:Suzhou University,2016.

[10] Gong Xiaojia. Exploration on Training Innovative Talents in New Engineering in the Practice Teaching of Comprehensive Universities [J].Journal of Higher Education,2017(12):141 - 142.

[11] Guan Hongyao,Gao Haitao,Hao Fei,Han Yali. Reform and Exploration of Practical Teaching of Mechanical and Electronic Engineering under the Background of New Engineering Education. China Modern Educational Equipment,2020(09):108-110. 